\title{
REGIONAL TRAINING INSTITUTE FOR NATIONAL RED CROSS AND RED CRESCENT SOCIETIES OF NORTH AFRICA AND THE MIDDLE EAST
}

From 15 November to 5 December 1972, the Regional Training Institute for National Red Cross and Red Crescent Societies of North Africa and the Middle East held its first session in Tunis. It was attended by thirty-one representatives of the National Societies of the following countries: Algeria, Egypt, Jordan, Lebanon, Mauritania, Morocco, Syria and Tunisia. The Society representatives, who included secretaries general and national officials of various operational services, met to consider how a Red Cross or Red Crescent Society could, in the humanitarian field, meet the needs of national communities in full process of development. The Institute was made welcome by the Tunisian Red Crescent whose President, Dr. Fourati, conducted the proceedings jointly with Mr. A. Schmid, League representative, and Mr. Rabah, Professor at the University of Tunis.

The delegates attended intensive courses given by a number of Tunisian leaders (sociologists, economists and managerial experts) on subjects such as the socio-psychological study of the human needs of national communities, different methods of management, specific problems of humanitarian action, problems of information, and Red Cross structures. Educational methods enabling National Society representatives to take an active part in the courses ensured the best possible results. Two and a half days were set aside for purely Red Cross training, one and a half of which were devoted to lectures and demonstrations on the Geneva Conventions, the activities of the ICRC and other international Red Cross bodies, and their combined operations.

The International Committee was represented by Mr. F. Payot, Regional Delegate for North Africa, who took an active part in the life of the Institute during the "Red Cross days" and at other times, when he dealt with themes of international humanitarian law, the International Red Cross, and the Red Cross and 


\section{IN THE Red Cross World}

disaster relief. He analysed the Geneva Conventions and led a discussion on ICRC operations, followed by practical exercises which gave the participants a better understanding of the difficulties which ICRC delegates had to contend with in cases of conflict.

The League representative in turn led a discussion which shed light on the League's functions and responsibilities, particularly regarding the co-ordination of international relief in cases of natural disaster, the development of National Societies, and Red Cross representation in international institutions.

Altogether, the participants showed keen interest in the training received. They carefully followed the lectures which made them aware of the constant need for re-adjustment by those who want to serve the Red Cross ideal in the present-day world.

\section{REGIONAL TRAINING INSTITUTE FOR WEST AFRICAN NATIONAL SOCIETIES}

With the co-operation of the Nigerian Red Cross Society, the League of Red Cross Societies held a Red Cross Youth Regional Leadership seminar for English-speaking National Societies of West Africa, at Ibadan, Nigeria, from 1 to 20 December 1972. The League was represented by Mr. D. Andreassen and Miss J. Brown, Assistant Directors of the League's Youth Bureau, while the ICRC was represented by Mlle F. Perret, Delegate. The seminar was held in the context of the training institutes established by the League for the training of experts to assume responsibilities within National Societies and promote the Red Cross idea in the social, economic and political life of their countries. One of the aims pursued was the training of cadres for youth sections in West African Red Cross Societies.

The Ibadan meeting was attended by twenty-four delegates selected from among leaders of Red Cross Youth sections in the following six countries: Cameroon, the Gambia, Ghana, Liberia, Nigeria and Sierra Leone. The programme, which included theore- 